\title{
LIFE VERTALIM: Methodologies for the Integrated Management of High Polluted Effluents from Food SMEs to Urban Sanitation Systems ${ }^{\dagger}$
}

\author{
Monica Gutierrez ${ }^{1, *}$, Susana Etxebarria ${ }^{1}$, Alberto Ciriza ${ }^{2}$, Luis Sancho ${ }^{3}$ and Jaime Zufía ${ }^{1}$ \\ 1 AZTI, Astondo Bidea, Edificio 609, Parque Tecnológico de Bizkaia, E-48160 Derio, Spain; \\ setxebarria@azti.es (S.E.); jzufia@azti.es (J.Z.) \\ 2 Consorcio de Aguas Bilbao-Bizkaia, Maestro José, E-49810 Sestao, Spain; aciriza@consorciodeaguas.eus \\ 3 Ceit-IK4 and Tecnun (Universidad de Navarra), 15 Paseo Manuel Lardizabal, E-20018 San Sebastián, Spain; \\ lsancho@ceit.es \\ * Correspondence: mgutierrez@azti.es; Tel.: +34-667-144-510 \\ + Presented at the 3rd EWaS International Conference on "Insights on the Water-Energy-Food Nexus", \\ Lefkada Island, Greece, 27-30 June 2018.
}

Published: 5 September 2018

\begin{abstract}
The main objective of the LIFE VERTALIM project is to demonstrate the efficiency of a holistic solution (including technical, legislative, social and environmental aspects) for the controlled integration of food industry wastewater in urban sanitation system with the compliance of all stakeholders. The artisan production of canned tuna is characterized by generating effluents with high organic and saline loads, which complicates their suitable treatment. This work shows two approaches to solve this problem. To begin, low-cost innovative solutions, through clean and eco-efficient production and wastewater pretreatment for the fish canneries. Then, the implementation of a real time control system (RTC) as a remote management system in the sanitation network that will allow the remote management of the urban and industrial discharges, based on the modeling of the collector network and WWTP in different scenarios.
\end{abstract}

Keywords: fish canning industry; food industrial wastewater; eco-efficient food production; real time control system; industrial wastewater management

\section{Introduction}

The Water Framework Directive (WFD) and other directives related to water have helped to strengthen the protection of the waters of the European Union (EU). However, due to decades of previous degradation and persistent ineffective management, there is still a long way to go before the quality of all EU waters is sufficiently good. At present, the provision of this vital resource cannot be guaranteed $100 \%$ and there are factors that make it foreseeable that, in 2030, the demand for water could be $40 \%$ greater than the available supply [1]. In this context, Spain is one of the EU countries with the highest water stress (average water stress index in Europe and Spain 0.14 and 0.32, respectively), as well as being the EU country where historically the investments in water they have less weight compared to operating costs [2].

Among the aspects that affect the water quality are the industrial sectors in which there is an important environmental impact caused mainly by the high-water consumption, the generation of wastewater and the production of waste. Within this framework, we must highlight the fish canning sector that produces effluents with high organic load, organic matter, oils and fats, nitrogen $(\mathrm{N})$, phosphorus (P), salts and solids) and salt content (10-50 times higher than the urban wastewater), generating a serious problem, both by its direct discharge to the sea (traditional method, although 
almost abandoned) and by the discharge to the corresponding wastewater treatment plant (WWTP). These loads can cause problems of inhibition in the biological treatment of the WWTP, so it is necessary to detect, quantify and establish corrective actions, even more, considering the accumulation of this type of companies and their seasonal nature. It may happen that, although individually each company located in the area is able to comply with the discharge regulations, if all of them were to be discharged simultaneously to the sanitation system, it would not be able to cope with that high point load.

Under this framework the European project LIFE VERTALIM (http://www.azti.es/vertalim) is born, with the main objective of the development of a holistic solution (technical, legislative, social and environmental) for controlled integration of the discharges of small food companies into the urban sanitation system. In order to comply with the stated objective, the project is based on 4 action blocks: (1) the minimization of discharges at source in the canning companies, (2) the implementation of the GSM tele control (global system for mobile communications) in the network of sanitation and in industrial discharges, (3) simulation and modeling for the control of discharges, and (4) the demonstration of the integral management system of discharges in the sanitation network (Figure 1). The demonstration test of the project is being carried out in the Biscayan area of Artibai, with a strong presence of industry in the canning sector, whose discharges have an important impact on the WWTP of Galtzuaran (Ondarroa).

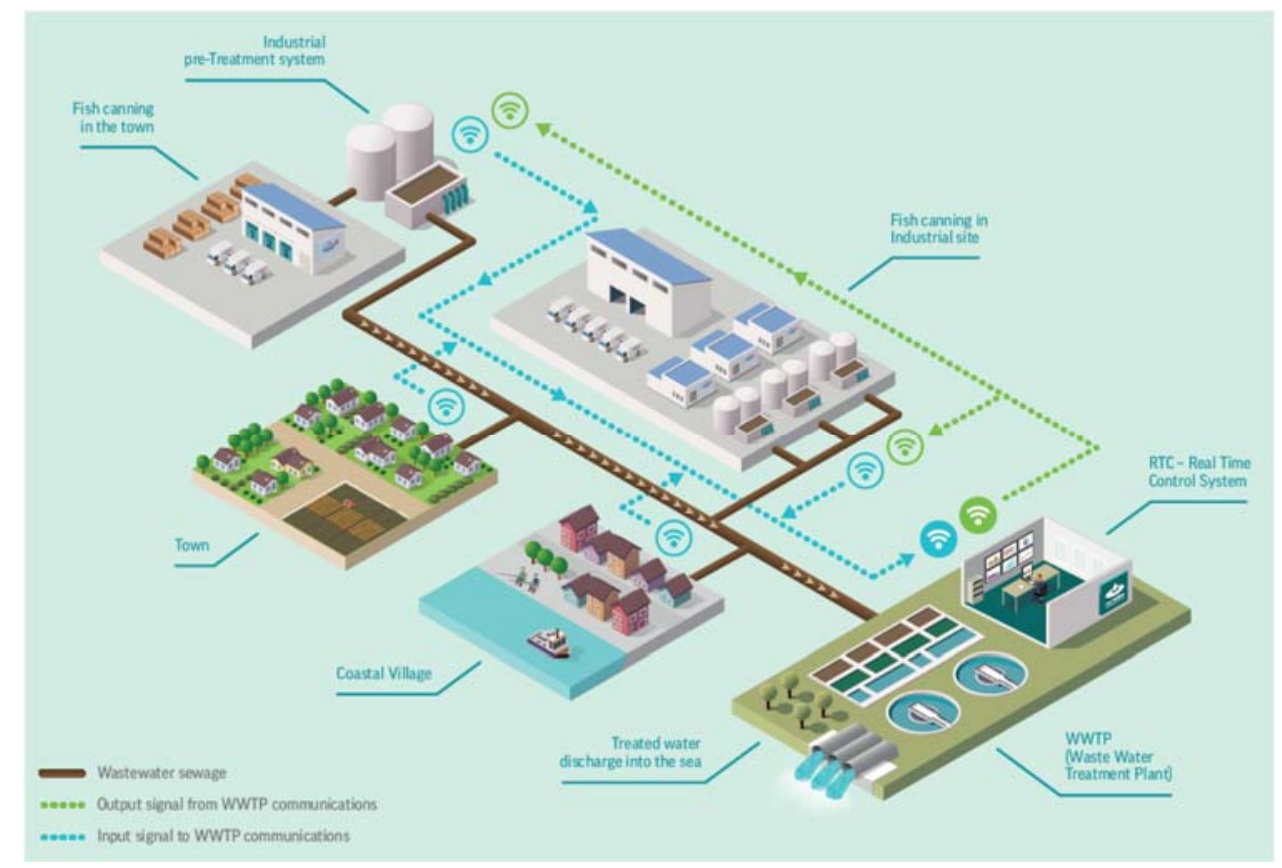

Figure 1. VERTALIM project schema: Controlled integration of industrial wastewaters in the urban sanitation system.

\section{Methodology}

\subsection{Description of the Demonstration Scenario}

The demonstration test of the project is being carried out in the Biscayan area of Artibai, more specifically, in the sanitation system that connects the towns of Berriatua and Ondarroa with the WWTP of Galtzuaran (Ondarroa). The main discharges connected to this network are from the two mentioned locations and an industrial area (polygon of Gardotza), where three of the four canning companies belonging to the project are located (Conservas Aguirreoa, Heisa and Marmar) and from Conservas Güenaga that is in Berriatua (Figure 1).

The change of water regulation promotes the prevention of the deterioration of all surface water state by incorporating industrial discharges into the sanitation system. For that reason, the companies that poured into the Artibai River, are pushing to have to carry out their industrial activity in a more 
efficient way. When they get it, they can discharge their effluents in the urban sanitation system without being a problem in the daily activity of the WWTP.

\subsection{Description of the Eco-Efficiency Tools For Industrial Production}

The eco-efficiency is the concept of doing more with less, applied at factory level; in other words, creating goods and services while preserving natural resources and reducing waste and pollution during manufacturing [3].

Cleaner Production is the continuous application of an integrated preventive environmental strategy applied to processes, products and services. It embodies the more efficient use of natural resources and thereby minimizes waste and pollution as well as risks to human health and safety. It tackles these problems at their source rather than at the end of the production process; in other words, it avoids the 'end-of-pipe' approach [4].

The first step is the environmental diagnosis, where the production aspects that may generate an impact in the environment are identified. So, several visits are made to each company to collect the production information. In addition, visits are made for the on-site observation of each process in order to detect possible inefficiencies, quantify the water consumption and detect sources and causes of pollution generation by collecting wastewater samples to analyze their contamination.

After the presentation of the Environmental Diagnosis report in each tuna canning industry, it is necessary to join the SME managers and the staff from production, quality and maintenance departments for a brainstorming session to get the best improvements measures aimed to reduce water consumption and decrease the wastewater pollution. After the evaluation of improvement measures, SMEs can select the measures of direct implementation.

\subsection{Analitycal Control Parameters for Water and Wastewaters}

The analytical characterization of wastewater pollution and the surface waters state is made according to Standard Methods for Examination of Water and Wastewaters [5]. The analytical control parameters are $\mathrm{pH}$, Temperature, Dissolved Oxygen (DO), conductivity, salinity, Total Suspended Solids (TSS), Chemical Oxygen Demand (COD), Biological Oxygen Demand (BOD), Grease and Oils, Ammonium Nitrogen $\left(\mathrm{NH}_{4}{ }^{+} \mathrm{-}\right)$, Nitrate-Nitrogen $\left(\mathrm{NO}_{3}{ }^{-} \mathrm{-N}\right)$ Nitrite-Nitrogen $\left(\mathrm{NO}_{2}{ }^{-}-\mathrm{N}\right)$ and Total Nitrogen, Phosphate and Silicate [5].

\subsection{Virtual Simulation Platform of Sanitation System}

The aim of the platform is the integration of industrial pre-treatment systems, collectors network and the WWTP management. The optimization of the sanitation system is achieved based on a time scale, appropriately managing both the ability to laminate the discharges in the pretreatment systems of companies, as well as the storage capacity in the network of collectors and the WWTP. This is intended to optimize the performance of the purification of the treatment plant, minimize the costs associated with such treatment, taking advantage of the chance of laminating effluents for treatment in low energy tariff time zones.

For that purpose, the optimization of organic and saline loads into the WWTP has been developed and validated at an industrial scale of a Real Time Control (RTC). This remote management system in the sanitation network will allow the intelligent management of different discharges, urban and industrial, based on the modeling of the operation of the collector network and the WWTP in different scenarios.

The development of the simulation platform consists of two different parts:

- Modelling of the SanitationNetwork: It includes the fluid-dynamic behavior of the waters that run through the pipe system, as well as the conditions in which the different pollutant compounds transport through the system. The simulation platform was made with comercial software MIKE Urban (www.mikebydhi.com). 
- Modelling of the Galtzuaran WWTP starting from the WEST simulation platform (www.mikebydhi.com) under the mathematical modeling motodology Plant-Wide Modelling (PWM) developed by Ceit-IK4 [6,7].

\section{Environmental Impact Indicators}

The objective of the environmental impact indicators is the quantification of the improvements due to the implementation of the project.

\subsection{Fish Canning Industries}

We have defined and quantified the environmental performance indicators in the canneries which will be used to verify the progress of the project as well to check the improvement of the wastewater quality and water management efficiency. Initial characterization of the following parameters is carried out in each company (Table 1).

The set of environmental indicators will be measured again after fish canned food companies have implemented the improvement measures identified previously.

Table 1. Environmental impacts indicators for Fish canning industries.

\begin{tabular}{cc}
\hline Indicator & Unit \\
\hline Water consumption & $\left(\mathrm{m}^{3}\right.$ water/Tn product $)$ \\
Water reuse & $\left(\mathrm{m}^{3} /\right.$ year $)$ \\
Generation of waste water & $\left(\mathrm{m}^{3}\right.$ wastewater $/$ Tn product $)$ \\
Degree of contamination & $\left(\mathrm{Kg}\right.$ of TSS $, \mathrm{Cl}^{-}, \mathrm{COD}, \mathrm{TKN} / \mathrm{Tn}$ product $)$ \\
\hline
\end{tabular}

\subsection{Surface Waters}

At the beginning of the project, artisanal canning companies carried out their discharges without treating through the river, with the consequent ecological damage, especially when dealing with sensitive areas. Therefore, one of the most important parts in this project is the monitoring of the state of surface water in the area and its recovery.

A sampling calendar has been established to monitor the quality of the receiving waters. During the duration of the project, three specific annual sampling campaigns are being carried out in the river section affected by the discharges of the companies, such as in the estuarine environment and the coastal area that receiving the discharges from the WWTP (Figure 2 and Table 2).

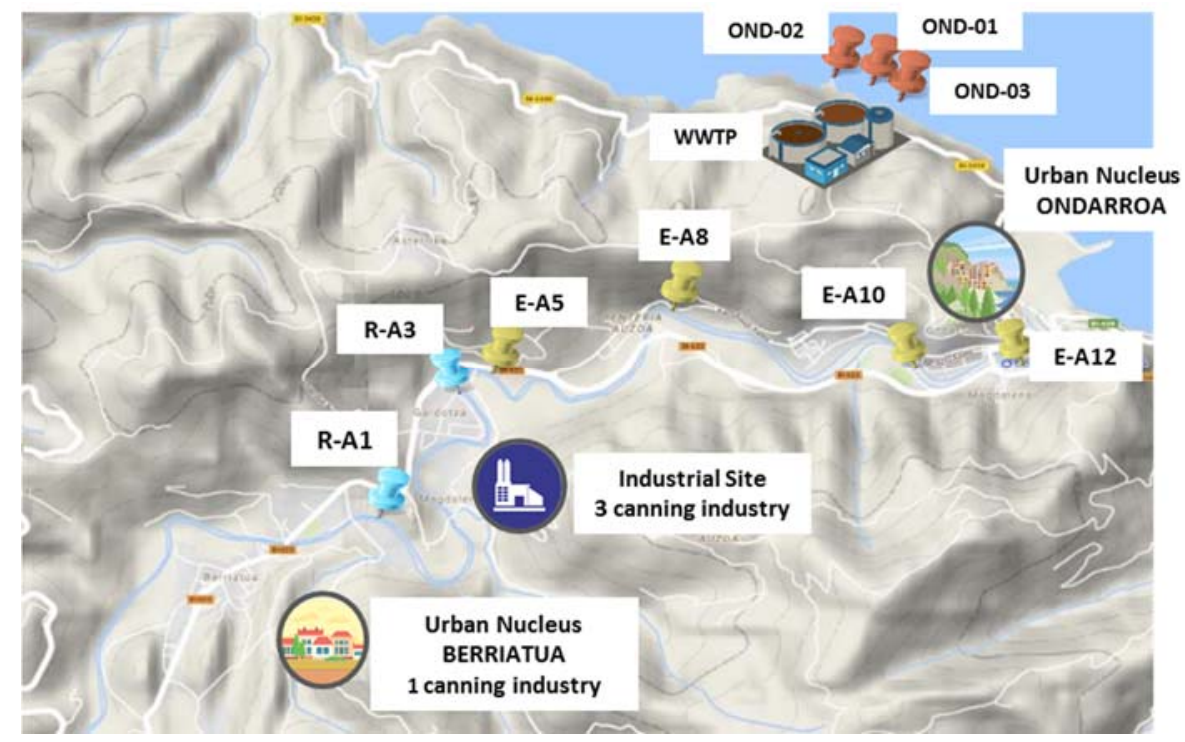

Figure 2. Sampling stations for the measurement of different variables in surface water. 
Table 2. Location of sampling stations.

\begin{tabular}{lllll}
\hline Zone & Tide & Code & GPS Position & Location \\
\hline River & Low & R-A1 & N43 18.720 W2 27.658 & Canneries discharge upstream (Berriatua) \\
River & Low & R-A3 & N43 19.163 W2 27.223 & Canneries discharge downstream (Berriatua) \\
Estuary & Low & E-A5 & N43 19.305 W2 26.600 & Ondarroa (Errenteria) \\
Estuary & Low & E-A8 & N43 19.178 W2 25.647 & Ondarroa (Bridge 1) \\
Estuary & Low & E-A10 & N43 19.192 W2 25.267 & Ondarroa (Pier) \\
Estuary & Low & E-A12 & N43 19.362 W2 25.238 & Ondarroa (Bridge 2) \\
Sea & Low & OND 1-3 & & Sea-near the WWTP \\
\hline
\end{tabular}

The variables related to the general physicochemical and biological indicators for water bodies have been selected, according to Annex V of the Water Framework Directive 2000/60/EC. Analytical measures (collected in Table 3) will be carried out. The comparison of the analytical data will allow to evaluate the environmental impact on water bodies of the actions carried out within the project.

Table 3. Measured physical-chemical variables.

\begin{tabular}{cc}
\hline Indicator & Unit \\
\hline $\mathrm{pH}$ & \\
Dissolved oxygen & $\%, \mathrm{mg} / \mathrm{L}$ \\
Temperature & ${ }^{\circ} \mathrm{C}$ \\
BOD & $\mathrm{mgO} / \mathrm{l}$ \\
Suspended Solids & $\mathrm{mg} / \mathrm{L}$ \\
Ammonium & $\mathrm{mgN} / \mathrm{L}$ \\
Nitrate & $\mathrm{mgN} / \mathrm{L}$ \\
Nitrite & $\mathrm{mgN} / \mathrm{L}$ \\
Silicate & $\mathrm{mgSi} / \mathrm{L}$ \\
Phosphate & $\mathrm{mgP} / \mathrm{L}$ \\
\hline
\end{tabular}

\subsection{Environmental Impacts (LCA)}

To assess the environmental impact of the proposed wastewater treatment management alternatives, Life Cycle Analysis (LCA) can provide reliable and scientifically accurate information for wastewater treatment processes decisions, with the aim of identifying more sustainable alternatives with the environment.

An initial approach has been made for the environmental impact assessment using the LCA (Life Cycle Analysis) tool as a picture of the initial situation before the start of the implementation of the actions that will arise during the project.

The concept of LCA has been widely used in industrial products [8,9]. Its application to food is, however, more recent. The objective of the LCA applied to food is to identify the problematic aspects and the possible options for environmental improvement throughout the production, distribution and consumption chain. Different comparative studies have been carried out to evaluate different production systems or management strategies [10,11].

In this case, we will analyze the environmental impact caused by the operation and discharge of the treatment plant and by the direct discharge of untreated water from the canneries to the Artibai river.

The functional unit of the study is the annual treatment of discharges associated with both the urban sanitation network and those associated with the production of canned fish (Table 4). The selected impact categories are shown in Table 5. 
Table 4. Inventory of the data related to the total amount of discharges, energy consumption and analytical parameters of the final discharges.

\begin{tabular}{ll}
\hline & Units \\
\hline Annual Production & $\mathrm{tn} /$ year \\
Annual discharges & $\mathrm{m}^{3} /$ year \\
WWTP energy consumption & $\mathrm{KWh} /$ year \\
\hline Ammonia & $\mathrm{mg} / \mathrm{L}$ \\
Ammonium, ion & $\mathrm{mg} / \mathrm{L}$ \\
Nitrate & $\mathrm{mg} / \mathrm{L}$ \\
Nitrite & $\mathrm{mg} / \mathrm{L}$ \\
Total Nitrogen & $\mathrm{mg} / \mathrm{L}$ \\
Phosphate & $\mathrm{mg} / \mathrm{L}$ \\
Phosphoric acid & $\mathrm{mg} / \mathrm{L}$ \\
Total phosphorus & $\mathrm{mg} / \mathrm{L}$ \\
NaCl & $\mathrm{mg} / \mathrm{L}$ \\
\hline
\end{tabular}

Table 5. Impact categories for environmental indicator.

\begin{tabular}{ll}
\hline & Unit \\
\hline Climate change & $\mathrm{kg} \mathrm{CO}$ eq \\
Aquatic eutrophication & $\mathrm{kg} \mathrm{P} \mathrm{eq}$ \\
Marine eutrophication & $\mathrm{kg} \mathrm{N} \mathrm{eq}$ \\
\hline
\end{tabular}

\section{Expected Results}

The main expected result is to avoid high polluted discharges to water bodies thorough the demonstration of effective and controlled integration of food industry wastewater in urban sanitation network by the agreement with all stakeholders. Results are expected at different levels (Table 6).

The application of eco-efficient measures in the Food SMEs processes for the wastewater optimization will allow to reduce $30 \%$ of the wastewater discharges to the environment, the reduction of food losses, and therefore the reduction of $40 \%$ in the high organic load to sewer system, aiming at the small businesses to fulfill the current environmental policy. Moreover, the integration of industrial discharges to the sewer system by means of the RTC and the virtual simulation platform of complete sanitation system will allow a reduction on the pressure over the sanitation structures. Finally, the discharge of effluents properly treated to natural environment will allow the global ecosystem protection and a significative reduction on water stress in the river basin. Figure 3 shows a numerical abstraction of the benefits expected from the execution of this project.

Table 6. Levels of impacts related to these industrial activities over marine and river ecosystems.

\begin{tabular}{ll}
\hline Level & Expected Results \\
\hline Food SMEs & $\begin{array}{l}\text { The application of eco-efficient measures in the Food SMEs processes for } \\
\text { industrial wastewater volume and pollution prevention }\end{array}$ \\
\hline $\begin{array}{l}\text { Water Sanitation } \\
\text { Management }\end{array}$ & $\begin{array}{l}\text { Development and validation at industrial scale of a real time control } \\
\text { system (RTC) for the optimization of organic and saline loads into WWTP } \\
\text { in Artibai Basin }\end{array}$ \\
\hline Environment & $\begin{array}{l}\text { Significant reduction of food products and water management and } \\
\text { treatment environmental footprints }\end{array}$ \\
\hline
\end{tabular}




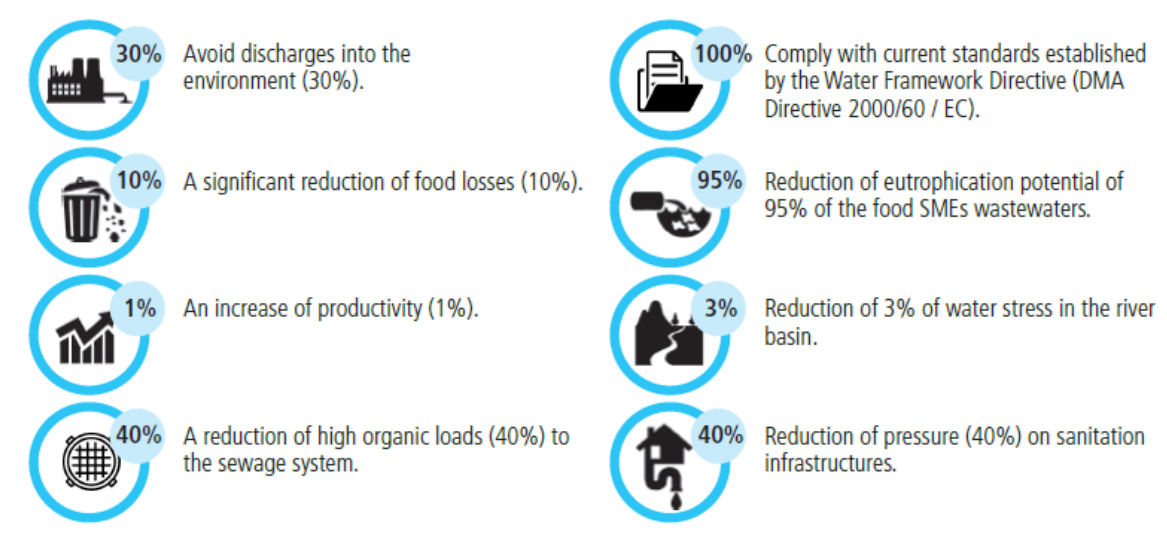

Figure 3. Expected benefits of LIFE VERTALIM proposal.

\section{Conclusions}

The present work shows the methodology for the implementation of a comprehensive management system for industrial and urban wastewater. To facilitate this management, it is proposed to reduce water consumption and its pollution in the canning industries through the application of eco-efficiency measures, as well as the development and validation on an industrial scale of a real time control system for the optimization of organic and saline loads into WWTP. On the other hand, during the execution of the project, environmental impacts will be monitored to determine the technical and environmental consequences derived from the actions carried out in it. This will allow to establish the technical and environmental viability of this integral management system of the sanitation network. In addition, clear criteria will be available to determine the minimum requirements necessary for the implementation of a sanitation network management system.

Acknowledgments: This study was partially funded by Life EU programme under LIFEI5 ENV/ES/000373 agreement.

\section{References}

1. Waughray, D. Water Security: The Water-Food-Energy-Climate Nexus; World Economic Forum, Island Press: Washington, DC, USA, 2011.

2. Integrated Pollution Prevention and Control Reference Document on Food, Drink and Milk Industries; European Commission: Brussels, Belgium, 2006.

3. Despeisse, M.; Davé, A.; Litos, L.; Roberts, S.; Ball, P.; Evans, S. A collection of tools for factory ecoefficiency. Procedia CIRP 2016, 40, 542-546.

4. Cleaner Production Program; UNEP-IE: Herndon, VA, USA, 1989.

5. APHA; AWWA; WEF. In Standard Methods for the Examination of Water and Wastewater, 19th ed.; Rice, E., Baird, R., Eaton, A., Clesceri, L., Eds.; American Public Health Association: Washington, DC, USA, 2012.

6. Grau, P.; de Gracia, M.; Vanrollenghem, P.; Ayesa, E. A new Plant-Wide modelling methodology for WWTPs. Water Res. 2007, 19, 4357-4372.

7. Lizarralde, I.; Fernández-Arévalo, T.; Brouckaert, C.J.; Vanrolleghem, P.A.; Ikumi, D.S.; Ekama, G.A.; Ayesa, E.; Grau, P. A new general methodology for incorporating physico-chemical transformations into multi-phase wastewater treatment process models. Water Res. 2015, 74, 239-256.

8. Baumann, H. LCA use in Swedish industry. Int. J. LCA 1996, 1, 122-126

9. Berkhout, F.; Howes, R. The adoption of life-cycle approaches by industry: patterns and impacts. Resour. Conserv. Recycl. 1997, 20, 71-94.

10. Cederberg, C.; Mattson, B. Life cycle assessment of milk production- a comparison of conventional and organic farming. J. Clean. Prod. 2000, 8, 49-60

11. Hospido, A.; Moreira, M.T.; Feijoo, G. Simplified life cycle assessment of Galician milk production. Int. Dairy J. 2003, 13, 783-796. 